\title{
A Case for Creation of Constitutional Roles for Our First Ladies, Particularly in Nigeria
}

\author{
Benjamin 0. Igwenyi \\ Department of Public and Private Law, Ebonyi State University, Abakaliki, Nigeria \\ Email: benigwenyi@gmail.com
}

How to cite this paper: Igwenyi, B. O. (2019). A Case for Creation of Constitutional Roles for Our First Ladies, Particularly in Nigeria. Beijing Law Review, 10, 1203-1210.

https://doi.org/10.4236/blr.2019.105064

Received: September 10, 2019

Accepted: November 30, 2019

Published: December 3, 2019

Copyright $\odot 2019$ by author(s) and Scientific Research Publishing Inc. This work is licensed under the Creative Commons Attribution International License (CC BY 4.0).

http://creativecommons.org/licenses/by/4.0/

(c) (i) Open Access

\begin{abstract}
The expression "First Lady" in all modern democracies of the world refers to the wife of the head of government, that is, the President or Prime Minister and they play significant roles in the realization of political party manifestoes of their various jurisdictions. In Nigeria, the Nigerian first lady even before independence in 1960 has been very visible, particularly in the execution of social welfare programmes, such as health care, education, and other minor services. In recent times, they have engaged in major projects such as building multi-billion hospitals as in the case of the wife of the Nigerian President, Mrs. Aisha Buhari in Daura, Katsina State and even a Private University at Adamawa State, her maiden state by the same first lady. The source of funding of these projects remains donations from government, government contractors and other citizens. The same is happening in the States of the Federation, where governors' wives embark on multi-billion projects which sources of funding remain opaque. This paper argues that time has come for the constitution to be amended to provide legal framework for the operation of these ladies so as to enthrone accountability in government and eradicate corruption in polity.
\end{abstract}

\section{Keywords}

First Lady, Role, Constitution, Amendment, Accountability, Corruption

\section{Introduction}

Over the years in this country and other countries, the wives of Heads of Government have played major roles in the governments of their various countries. These ladies of style and flamboyance have become so visible in the governments of their countries, yet no person can point to any law specifically creating roles for them save the fact that they are wives of the sitting Head of State, such as 
President or Prime Minister as the case may be. Some of these women have done so well in their countries in charity work and other spheres of life that they are internationally acclaimed, while some, like in the case of Philippines turned themselves into Jezebels of modern times. Therefore, there is the need to give legal framework to this position particularly in Nigeria where wives of Governors of the States and Local Government Chairmen also go by the title of "First Lady" in their various jurisdictions. It is our thinking that if the roles of the First Lady are itemized in a section of the constitution or any other law, they will be more focused and accountable and the country will be better for it.

Consequently, this paper attempts to look at who is a First lady i.e. the meaning of First Lady, the origins of the title; notable roles played by First Ladies in the past, before we conclude with a case for the First Lady by way of legislation giving them powers and functions so that they can be accountable at the end of their tenure unlike what is happening in Nigeria today where First Lady projects are personalized.

\section{The Meaning and Origins of the Office of the First Lady}

The word "First Lady" refers to the wife of a sitting Head of State in the United State of America. The acronym is "Flotus" meaning First Lady of the United States (Wikipedia, 2019a, 2019b). It has also been defined as "the wife of the leader of a state" (Hornby, 2018). The title, which was first used in the United State of America, was associated with Marta Washington, who was referred to as The Inaugural Holder of the title on the $30^{\text {th }}$ of April, 1789. She was addressed as "Lady Washington". According to legend, the title "First Lady" in written form was used in 1849 to describe Dolley Madison at her funeral in a eulogy delivered by President Zachary Taylor. The words also appeared in a diary where William Horward Russel made an entry dated November 3, 1863 referring to the "First Lady in the Land". The title gained nationwide recognition in the United States in 1877 when a Newspaper journalist Marcy C. Ames referred to Lucy Web Hayes as the "First Lady of the Land" while reporting the inauguration of the husband, Rudaford B. Hayes as the President of United States of America. By 1930s, the title had spread from the United States to other countries of the world.

It is instructive to note that in the US, the wife of the Vice President is sometimes referred as the "Second Lady" of the United States. It is also instructive to not that several women who were not presidents' wives have served as First Lady in the United States of America and this occurs where the President was a Bachelor or a Widower or where the wife of the President was unable to fulfill the duty herself. In such situations, female relatives or friends of the President used to occupy such position. Such was the case of Marta Jefferson Randoff during Jefferson's Presidency; Marta Harrison Mckee during Harrison's Presidency upon her mother's death and lately Chelsea Clinton when the mother was too busy as a Senator of the United States (Wikipedia, 2019a, 2019b). 


\section{First Ladies in Nigeria}

It is noteworthy to say that in Nigeria, the concept of First Ladyism was part of our colonial history where the wives of our colonial officials such as Lady Lugard and others performed as the hostesses of the State House from 1914 to September 301960 when Lady Robertson quit the stage. On her quitting the stage, Flora Azikiwe (1960-1966) played the role and handed over to Victoria Aguiyi Ironsi (16 $6^{\text {th }}$ January 1966-July 1966). The wife of General Gowon (1966-1975) who took over from Ironsi was a little visible. Other first ladies from General Murtala Mohammed's wife to the Obasanjo years as a Military Head of State to Alhaji Shehu Shagari and General Buhari were not very visible and remarkable. It could be said that it was from 1985 when Maryam Babangida became the wife of Military President Babangida that the position became alluring, vibrant and very purposeful as the woman traversed all aspects of social life of the common woman and in fact women in general by the introduction of "Better Life for Rural Women" (Ajayi, 2010). Ever since that time, the position has been held by Mrs. Maryam Abacha, Justice Fatima Abubakar, Late Mrs. Stella Obasanjo, Mrs. Turai Yar'Adua, Dame (Dr.) Patience Goodluck Jonathan and now Mrs. Aisha Muhammadu Buhari, who recently built and handed over multi-billion Mother/Child Hospital over to the Katsina State Government where her husband hails from.

\section{The Role of First Ladies in Historical Perspectives}

It is important to state from the onset that the position of the First Lady is not an elective one, carries no statutory duties and no salary equally, but they have been visible in the governments of their countries. In the government of United States of America where it started, some of the First Ladies have been known for one project or the other which touched the lives of the people. Lady Dolley Madison, who popularized the First Ladyship in America was said to have engaged in assisting orphans and women to better their lot. Many orphans and destitute women of her time received benefits of numerous dimensions. She was said to have risked her life saving iconic treasure during the war of 1812 .

Another lady of note, Eleanor Roosevelt in the 1930s virtually took over the government of the United States of America because of President Franklin D. Roosevelt's illness which kept him paralyzed. Lady Bird Johnson was involved in environmental protection and beautification. Pat Nixon encouraged volunteerism and traveled extensively abroad just as Betty Ford supported Women's right in all its ramifications. In the same vein, Roseline Carter aided people with mental disabilities just as Nancy Reagan founded the "Just Say No to Drug" awareness campaign and only lately, Mitchelle Obama is concerned with tackling obesity among children. In Nigeria, particularly from 1985, Maryam Babangida used her "Better Life for Rural Women" programme to fight for the social needs of rural women and children in Nigeria. Such programmes as National Programme on Immunization for all child killer diseases, soft loans for rural women 
to farm, girl-child education and campaign for women to take part in political activities such as elections and representation in government and appointive basis (ratio) became frequent features of the Nigerian government at all levels. Wives of local government Chairmen and Governors became visible and took up offices in local government headquarters and States Capitals. It became compulsory for the Minister of Women Affairs to be a woman who must relate directly with the First Lady for the execution of programmes involving women and children. Maryam Babangida so dressed elegantly that she was loved by every person though she was wife of a military Head of State.

After Mrs. Babangida, came Miriam Abacha in 1993 who floated her own outfit and did her best to reach the much she could. Following Mrs. Abacha was Hon. Justice Fati Lami Abubakar who established the Health Care Trust which was aimed at taking care of the health needs of abnormal children and of course their mothers. In the year 2007, Turai YarAdua stepped in and introduced her own brand of programme which was aimed at uplifting women and children. In the year 2010 precisely by May, Dame Patience Goodluck Jonathan floated her Women for Change Initiative which was/is aimed at ensuring greater women participation in politics. She went to all parts of the country, making a case for women to be elected as Councilors, State Assemblies Members, National Parliamentarians, Governors and if possible President. Women were given cash and supported with goodwill to take part in especially the 2011 elections.

The wives of State governors have not faired less. For example, the wife of the former Edo State Governor, Mrs. Eki Igbinedion introduced Ida Renaissance which was aimed at discouraging young girls from going to Europe where they go to prostitute in Italy and other European nations. The programme was so successful that many ladies have been brought back to the country and rehabilitated to take up genuine businesses. Skill acquisition centres were established in all parts of the State to prevent the young girls from leaving the state for the so-called greener pastures.

In Ebonyi State, the wife of the first executive governor, Mrs. Eunice Ukamaka Egwu (1999-2007) established the Widow Care Centre which was aimed at taking care of widows, widowers and their children. In the same vein, the wife of the immediate past Governor of Ebonyi State, Chief Mrs. Josephine Nwuzor Elechi had established her own pet project called MCCI, meaning Mother and Child Care Initiative, which has made Ebonyi State International Centre for VVF treatment. Here women who have had tearing of their organs during abnormal childbirth have been treated, repaired, rehabilitated and sent home. At the last count, over 1500 women had been so treated irrespective of State of origin. The wife of the current Governor of Ebonyi State, Mrs. Rachael Ogonna Umahi on coming to office in 2015 floated her own project under the Family Succour and Upliftment Foundation.

In similar vein, other state governors' wives and local government chairmen have one programme or the other touching on the lives of women and children and even men. 


\section{Constitution Distinguished from Mere Convention}

It is perhaps necessary at this point to make one or two comments on the word "constitution" and the expression "constitutional convention". The constitution of a country is the fundamental law of the land which determines the distribution of powers, between the three main arms of government i.e. the executive, the legislature and the judiciary and their relationship with the ordinary citizen. It has been severally defined by several authorities including the legendary $O$. Hood Philips. According to the learned author: The word "constitution" is used in two different senses, the abstract and the concrete. The Constitution of a State in abstract sense is the system of laws, customs and conventions which define the composition and power of organs of the State, and regulate the relations of the various State organs to one another and to the private citizen. A "constitution" in the concrete sense is the document in which the most important laws of the constitution are authoritatively ordained (Hood Philips, 2001).

Another definition worthy of mention is that given by Uthman Mohammed of the Supreme Court of Nigeria in the popular case of Attorney General of Abia State \& 35Ors v. Attorney General of the Federation (2002). According to the Law Lord: The Constitution is what is called the grundnorm and the fundamental law of the land. All other legislations in the land take their hierarchy from the provisions of the Constitution. By the provisions of the Constitution, the laws made by the National Assembly come next to the Constitution, following by those made by the House of Assembly of a State.

Before concluding on what we mean by Constitution, a definition from the Black's Law Dictionary is pertinent. According to the authors of the dictionary, constitution means: "The fundamental and organic law of a Nation or State that establishes the institutions and apparatus of government, defines the scope of government sovereign powers, and guarantees individual civil rights and civil liberties" (Garner, 2004).

From the above, we can see that the constitution of a country has a binding force on all authorities and persons within the country (Nigeria, 1999). Constitutional convention on the other hand which is where the role of First Ladies fall in means rules of political practice which are regarded as binding by those whom they concern-especially the sovereign and state men-but which will not be enforced by the courts if the matter came before them (Hood Philips, 2001). That is to say that the current role being played by first ladies such as organizing Christmas parties for children during Christmas celebrations, going to the hospitals to receive the first babies of the year, building child friendly hospitals, air port receptions for visiting foreign leaders and their wives are mere conventions which cannot be legally enforced if breached, unlike constitutional provisions which if breached can lead to litigations between the parties.

Conclusively, amendment of the constitution as canvassed in this paper is to change the legal position now so that the role(s) of the First Lady can be vividly captured with relevant stipulations that will enable the first lady to perform and 
be accountable to the citizens of this country. Happily, section 9 of the 1999 Constitution of Nigeria provides for the procedure for the amendment of the constitution which is two-third majority of the members of the National Assembly made up of the Senate and House of Representatives and two-third majority of the 36 States Houses of Assembly in Nigeria. It is only when this form of majority is recorded in the national and state legislatures that any part of the constitution can be amended.

\section{Way Forward/Recommendations}

In the light of the above, and particularly of the fact that these First Ladies have operated at their whims and caprices without legal co-ordination, we hereby propose that a legal framework be put in place to harmonize this useful institution. Consequently, we propose as follows:

First, the constitution should be amended to recognize the position of the First Lady at the Federal and State levels with their duties and or functions itemized. This will involve stating that the office of the First Lady is hereby created as contained in our constitution where the position of the President is created, (Nigeria, 1999). The qualification for the office shall also be itemized, that is, to say she should be married to the President, should be a citizen of Nigeria, and should be educated up to school Certificate Level. The framework shall include the constitutional duties as in the case of the President whose duties are itemized in sections 5(1) (a) and (b), 5(4), 12(1), 175, 147(2), 151, 214(1), 58 and 59 etc, (Nigeria, 1999).

The same thing will apply in the case of Governors' wives. Implicit in this recommendation is that the First Lady's office will now have a budget of her programmes for each financial year and they will operate within that and that should check the craze for corruption. The office shall be made subject to oversight by the legislatures as in the case of elected or appointed officers.

This will enable us to have accountability in this institution. A situation where the wife of the President comes on board and decides to pick whatever programme that tickles her fancy is quite wasteful. In some situations, these Ladies particularly at State levels establish their "pet projects" as private enterprise outside government control thereby converting indirectly the funds of the State. Example of these are everywhere to be seen starting with the Child Care Trust which is established at Bwari, Abuja by late, Mrs. Stella Obasanjo and Widow Care Centre Abakaliki, Ebonyi State owned by Mrs. Eunice Egwu (wife of former governor Sam Egwu of Ebonyi State) to mention but a few, which are now private enterprises of the former first ladies.

Secondly, as fallout from the above, if the functions of the First Lady are captured within the law, it will not be easy for a new First Lady to start thinking of a new programme. Only God knows what could have been the case if each President or Governor is given chance to adopt his own pet project instead of taking over and governing the State as provided in the constitution and the laws made 
by various State Houses of Assembly nationwide.

Thirdly, a legal framework for the operation of First Ladies will outline the source of revenue which the First Lady should use while in office. A situation whereby the First Lady uses her position to coerce private businessman and contractors and top civil servants to contribute money for the said pet project is one of the engines of corruption. This is because contractors to government and top public officers who want to retain their positions are coerced into making donations which are never accounted for and which is only known to the First Lady. No wonder most of these programmes particularly at the States die as soon as the originator leaves office hence legal framework will ensure continuity and act as a check against corruption.

Finally, it is not in doubt that corruption has been a big factor in the retardation of growth of most Africa democracies. "Corruption" which is simply the use of one's position either in the public or private sphere to get underserved benefits for oneself or another person is a source of worry to all decent citizens as same has caused immeasurable damage in the development of the country as funds meant for even development of the society often disappear into private pockets. It is therefore pertinent to combat this malady which have been defined by the Black's Law Dictionary as: The act of doing something with an intent to give some advantage inconsistent with official duty and the rights of others; a fiduciary's or official's use of a station or office to procure some benefits, either personally or for someone else contrary to the rights of others (Garner, 2004). Therefore all avenues where corruption could occur should be blocked through legislation. Where the position of First Lady is now provided for as suggested in the constitution, her duties and sources of income and expenditure will be known as she would now be tried as public officer if she abuses her office, unlike the present situation where her position is just ceremonial and where she could not be held liable for any offence as her office is not provided for by law in strict sense.

\section{Conclusion}

The position of First Lady appears to be covered by constitutional convention, but the position seems to have grown in relevance and should no longer be left as a matter of convention. A specific constitutional provision or some sort of legal recognition for the position and roles will strengthen the First Family and become more useful to the Nigerian State and in fact other democracies where the wife of President or Prime Minister is allowed to perform. In this sense, Nigeria will be breaking the ground by being the first country to formally recognize legally the office of the First Lady with its attendant advantages.

\section{Conflicts of Interest}

The author declares no conflicts of interest regarding the publication of this paper. 


\section{References}

Ajayi, K. (2010). The Concept of First Lady and Politics in Nigeria. Council for the Development of Social Science Research in Africa (CODESRIA).

http://www.codesria.org/

Attorney General of Abia State and 35Ors v. Attorney General of the Federation (2002). 6 NWLR (Pt. 763), p. 479. (NWLR Stands for Nigerian Weekly Law Report and Pt Stands for Part).

Garner, B. A. (Ed.) (2004). Black's Law Dictionary (9 $9^{\text {th }}$ Edition, pp. 353 and 397). West Publishing Company, Dallas.

Hood Philips, O. (2001). Constitutional and Administrative Law ( $8^{\text {th }}$ Edition, p. 5). Sweet \& Maxwell, London.

Hornby, A. S. (2018). Oxford Advanced Learner's Dictionary of Current English (9 $9^{\text {th }}$ Edition, p. 586). Oxford University Press, Oxford.

Nigeria (1999). 1999 Constitution of the Federal Republic of Nigeria (as Amended), Federal Government Printer, Abuja.

Wikipedia (2019a). First Lady.

https://en.wikipedia.org/wiki/First_Lady_of_the_UnitedStates

Wikipedia (2019b). Josephine Elechi. 